\title{
Modern Challenges in the Field of Legal Regulation of the Digital Economy
}

\author{
Anishchuk V.V. ${ }^{1,{ }^{*}}$ Lenher Ya.I. ${ }^{1}$ Tereshchuk G.A. ${ }^{2}$ \\ ${ }^{1}$ Lutsk National Technical University, Lutsk, Ukraine \\ ${ }^{2}$ Ternopil National Economic University, Ternopil, Ukraine \\ *Corresponding author. Email: v.nishchuk@lutsk-ntu.com.ua
}

\begin{abstract}
The paper is devoted to the study of the development of the digital economy, its essence and changes that occur in society in connection with digitalization. The influence of the digitalization process on the legal sphere is investigated; some issues of the interaction of law and the digital economy are highlighted. It is noted that the digital economy predetermines the transformation of the whole legal system. The paper describes the models of statutory legal regulation of relations in the digital economy in the developed countries of the world. The study analyzes the stages of the legal provision of the digital economy in Ukraine. It is noted that digitalization began to be discussed in a qualitatively new way at the state level in 2019 after the election of a new President of Ukraine and the renewal of the composition of the parliament based on the election results. The digital economy requires proper legal regulation, which should be ensured by the adoption of appropriate unified law and, based on it, a set of flexible regulatory acts aimed at regulating certain legal relations associated with the use of artificial intelligence, responsibility for offenses in the information field, the use of robots in labor and issues of responsibility for harm caused by them, etc.
\end{abstract}

Keywords: right, legal regulation, digital economy, digitalization, digital reality, digital technologies

\section{INTRODUCTION}

Today, society is at the stage of fundamental changes associated with the introduction of digital technologies in all spheres of public life. The developed countries of the world have felt the consequences of the digital economy and virtual space for a long time age. For Ukraine, this is a relatively new challenge. For a very long time, our state lagged behind in technological development. However, today, the digital world has penetrated in Ukraine and it is rapidly developing in all spheres of public life. New concepts and relations that arose in connection with digitalization and gradually developed in other countries "broke into" the life of Ukrainian citizens and changed it dramatically. We can no longer confine ourselves to the fact of the development of digital technologies in our country. Relations, which were unknown until recently, require proper legal consolidation and regulation.

\section{METHODS}

In the course of the study, general scientific and special legal methods were used, particularly, analysis, induction, deduction, synthesis, analogy, generalization, historicallegal, comparative-legal, normative-dogmatic, etc.

\section{RESULTS}

The study revealed the global impact of digitalization and the digital economy on the legal sector. The rapid development of digital technology has led to the emergence of new public relations that require legal regulation. The stages of introducing the legal support of the digital economy in Ukraine are analyzed; the main problems and their solutions in this field are identified.

\section{DISCUSSION}

Modern conditions do not leave the grounds to imagine planning the development of economics, politics, culture, education, science in isolation from inevitable digitalization. Since the digital economy has become a full-fledged reality, in which completely new social relations that require legal regulation emerged, the question of the emergence of a new concept of right, which can be called digital, arose. Indeed, without the use of digital processes and technologies, the economic development of Ukraine is doomed to a permanent lag. The concept of the "digital economy" is a relatively new phenomenon. There are many definitions of the concept of the "digital economy" in the world literature. Various concepts reflect the time and modern trends, especially in the field of technology. As a result of scientific research, it was determined that the digital economy is a system of 
economic, social, and cultural relations based on the use of digital technologies [1]. The peculiarity of the digital economy is that real processes of distribution of material goods and relations arising from their regulation are going to be superseded by a virtual, digital world, which has an artificial, intangible nature, where digital data, information systems, and information itself are of the greatest value. As P.P. Baranov reasonably noted, the domestic legislator for a long time rather passively responded to these changes, which might lead to unexpected consequences and destabilization of entire sectors of the economy [2].

Digitalization primarily affects the sector of legal regulation. In this area, new social relations, which previously either did not exist or did not need legal regulation, or could not be objectively regulated by law, emerge. Thus, the emergence of the following relations is observed in the field of legal regulation:

first, the subjects of which are virtual or digital persons; second, related to legally significant personal identification in the virtual space;

third, arising in connection with the implementation of human rights in the virtual space (the right to access the Internet, the right to oblivion, the right to "digital death," and others); and

fourth, focused on the use of robotics. According to analysts, in ten years, almost all jobs in global financial centers will be occupied by robots. According to EY, in the next twenty years, $47 \%$ of occupations in different countries will highly likely be automated [3]. According to analysts, in the field of labor relations of the International Bar Association (IBA), which was presented in the report "Artificial Intelligence, Robotics and Their Impact on the Workspace," in the near future, 1/3 of the jobs occupied by graduates of universities can be replaced by machines and software; moreover, the advantages of countries with cheap labor will be eliminated due to the fact that robots are cheaper than human workers [4];

fifth, evolving with respect to atypical objects, information, digital technologies created through the use of new digital entities (cryptocurrencies), and objects of the material world, as well as those associated with the use and circulation of both;

sixth, associated with the use of digitized information arrays, information databases; digitization of actions and operations, due to which state functions are implemented, state and municipal services are rendered, electronic participation of citizens in the management of society and the state is ensured; performance of actions in the virtual space aimed at the creation, amendment, and termination of legal relations, the exercise of rights and the fulfillment of obligations that form their legal content; the use of automated actions (the Internet of Things), information security assurance, and others [5].

Mankind has entered the era of "Electronic Digit," which, in the figurative expression of one of the founders of Microsoft, Bill Gates, "is able to generate thoughts and actions." The development of information and communication technologies gave a new impetus to scientific and technological progress and led to the transition of a society to the information, post-industrial (based on the generation of knowledge) stage of socioeconomic development, forming a new reality [6]. This reality is changing the impact and the essence of many social institutions and regulators, including those of law. The law takes on a new meaning, it becomes not only a means, a tool ensuring the penetration of digital technologies and their use in various spheres of public life but also an object of the impact of digitalization. The content, the form, and the driving mechanism of law are changing.

Many countries of the world search for a model of statutory legal regulation of public relations in connection with the transition to digital technologies, regulations in the field of the digital economy are being adopted in accordance with this process. Particularly, the UK has the UK Digital Economy Act, which contains the Regulation on Electronic Communications of Infrastructure and Services, which restricts access to Internet pornography; Regulation on the Protection of Intellectual Property in Connection with the Use of Electronic Communications; Data Exchange Provisions, etc. The USA has a Digital Millennium Copyright Act. France has the existing Law on Confidence in the Digital Economy, which contains definitions of the concepts of electronic trade and commerce and others [7]. For Ukraine, the experience of Belarus in the field of the digital economy, where Decree "On the Development of the Digital Economy" was adopted on December 21, 2017, is important. The main points of the decree refer to the creation, training of neural networks and other algorithms in specialized sections of artificial intelligence, the implementation of the results of this activity; activities of cryptocurrency exchanges; development, maintenance, operation, and implementation of unmanned vehicle control systems; development and application of medical technologies, biotechnologies; educational activities in the field of information and communication technologies, particularly, through the Internet; the procedure for making payments using electronic money, conducting currency transactions related to the achievement of capital within the established manner, etc. is simplified. Belarus has become the first country in the world to legalize smart contracts [8]. Thus, a variety of legislative reactions of states to digitalization can be traced. It is obvious that all they are united by a clear understanding of the need for legal influence on existing processes but the application of clear strategies has not yet been traced. Unfortunately, the transformation of law and legislation of almost all countries does not correspond to the pace of changes taking place in the digital world.

Ukraine has also taken the path of the legal provision of the digital economy. Thus, in 2013, the Cabinet of Ministers of Ukraine adopted the Strategy for the Development of the Information Society in Ukraine, which defined the objectives, basic principles, strategic goals for the development of the information society, as well as tasks aimed at achieving them and main fields, stages, and mechanisms for implementing this Strategy in perspective 
until 2020. This document also defines the electronic economy as a form of economic relations in the field of production, distribution, exchange, and consumption of goods, works, and services provided in electronic form using information and communication technologies [9]. In 2015, Ukraine joined the Declaration of the first meeting of the EU Eastern Partnership Ministers on the digital economy, thereby demonstrating its intentions and willingness to cooperate with the EU in this field [10].

One of the waypoints to the legal regulation of digitalization was the adoption by the Cabinet of Ministers of Ukraine of the Concept of development of an electronic services system in Ukraine in 2016 [11], of the Concept of development of electronic governance in Ukraine [12], the Concept of development of electronic democracy in Ukraine, and an action plan for their implementation in 2017 [13], as well as the adoption of the Law of Ukraine "On Electronic Trust Services" in 2017 [14].

The next step was the approval in 2018 of the government Concept for the development of the digital economy and society of Ukraine for 2018-2020, aimed at accelerating the technological development of Ukraine and ensuring the accelerated implementation of digital technologies in the economy and social sphere of the country [15]. This concept provides for the implementation of measures to introduce appropriate incentives for the digitalization of the economy, public and social spheres, awareness of the challenges and tools for developing digital infrastructures, the acquisition of digital competencies by citizens, as well as identifies critical areas and projects of digitalization, promotion of the domestic market, the use and consumption of digital technologies. The concept defines the notions of the digital economy, digitalization, digital technologies, indicates the main goal of digitalization and its principles, the main goals and fields of digital development, and so on.

Thus, it can be stated that Ukraine made the first steps to develop the digital economy and the legal base for ensuring the penetration of digital technologies in various spheres of public life. However, many issues remained unsolved.

The digitalization began to be discussed in a qualitatively new way at the state level in 2019 after the election of a new President of Ukraine and the renewal of the composition of the parliament based on the election results. According to the ex-Prime Minister of Ukraine Alexey Goncharuk, it is envisaged to develop a plan for the total digitalization of the country. In September 2019, the Ministry of Digital Transformation, or Mintsyfra, was created in Ukraine by transforming the State Agency for Electronic Governance of Ukraine. On September 18, 2019, the Resolution of the Cabinet of Ministers of Ukraine approved the regulation on the Ministry of Digital Transformation [16]. The Mintsyfra is the main body in the system of central executive bodies, which ensures the formation and implementation of state policy in the areas of digitalization, digital development, digital economy, digital innovation, e-government, and e-democracy, the development of the information society, informatization; in the area of development of digital skills and digital rights of citizens; in the areas of open data, the development of national electronic information resources and interoperability, the development of the infrastructure of broadband Internet access and telecommunications, electronic commerce and business; in the area of provision of electronic and administrative services; in the areas of electronic trust services and electronic identification; in the area of development of the IT industry. According to this provision, the main tasks of Mintsyfra are the formation and implementation of state policy in the areas of digitalization, digital development, digital economy, digital innovation, e-government, and e-democracy, the development of the information society, informatization; in the area of development of digital skills and digital rights of citizens; in the areas of open data, the development of national electronic information resources and interoperability, the development of the infrastructure of broadband Internet access and telecommunications, electronic commerce, and business; in the area of provision of electronic and administrative services; in the areas of electronic trust services and electronic identification; in the area of development of the IT industry.

The goals that are planned to be achieved by 2024 may be found on the website of Mintsyfra, particularly: 1) 100\% of public services are available to citizens and businesses online; 2) $95 \%$ of the transport infrastructure, settlements and their social facilities are provided with access to highspeed Internet; 3) 6 million Ukrainians are involved in a digital skills development program; 4) $10 \%$ share in the country's GDP is the IT sector. The Ministry of Digital Transformation of Ukraine together with other government bodies and international partners contribute to the introduction of electronic services in many areas of the economy, construction, land services, environment, business registration, social benefits, state assistance, and so on.

To implement the tasks, Mintsyfra has started a very proactive run. The Digital State project, within the framework of which the Action online service combining a mobile application and a portal for providing public services was created, was launched. Since February 6, 2020, the Action mobile application was launched, where today there is a digital driver's license, a digital certificate of registration of a vehicle, and a BankID. In March, the Action application should include a digital auto insurance policy, a digital student ID, a digital passport and a digital foreign passport; in April, car fines, a digital tax number, data from the register of legal entities, individual entrepreneurs, and public organizations, the registry of rights to real estate, and the register of encumbrances of movable property and land cadastre.

Thus, we see that digitalization will affect everyone. The dictionary of the modern Ukrainian language and the slang "Mislovo" chose the word "диджитализация" as the word of 2019. The term topped the list of the most searched words in the dictionary with a great margin and the number of its views increased by $1.535 \%$ compared to the 
last year [17]. The main criteria for choosing the word of the year in this Internet resource is its popularity and social significance. In this regard, it makes no sense to conduct a further discussion about whether digitalization is necessary for society and, particularly, for our state. It is more expedient and relevant to find out the main pros and cons that the digitalization of the economy will bring us in order to be ready for new challenges and prepare the appropriate legal framework.

We agree with the opinion of $\mathrm{O}$. Vinnyk that the formation of the digital economy and its social orientation requires adequate legal regulation, an important part of which is not only the definition of the concepts that characterize it (subjects, objects, means, links, etc.) but also timely adoption of relevant legal standards. Although, there are a significant number of legislative acts in Ukraine that regulate relations in this area and consolidate the corresponding concepts, which were analyzed in the study, however, the problem of unification of terms inherent in the digital economy needs to be addressed, as well as they should be consolidated in a codified act, which may be embodied in the Law on Digital Economy." This will improve the legislation in this area in terms of content, form, system, and adaptation to the best world standards, taking into account our own achievements, and will possibly create more perfect legal regulation of electronic economy relations compared to that already existing abroad [18]. In addition to the traditional codified legislation, flexible acts should be developed on its basis that will regulate individual relations arising with the development of the digital economy, such as the use of artificial intelligence, responsibility for offenses in the information sphere, the use of robots in the labor sphere and issues of responsibility for harm that they have caused, and so on.

\section{CONCLUSION}

Summing up the above, it is possible to conclude that the digital economy determines the emergence of new social relations, the special properties of which should be taken into account in legal regulation. The Ukrainian digitalization process has its own features. For a very long time, our state lagged behind in technological development. New concepts and relations that arose in connection with digitalization and gradually developed in other countries "broke into" the life of Ukrainian citizens and changed it dramatically. The domestic legislator's response to these changes was extremely passive. The first steps to develop the digital economy and its legal provision were made as late as in 2013. Since 2019, this process has significantly intensified, a number of reforms and innovations in the field of digitalization have been implemented. The critical importance of the digital economy for economic growth and overcoming the crisis has been recognized. Despite this, many issues remain unsolved. There are a significant number of legislative acts in Ukraine that regulate relations in the area of digitalization and consolidate the corresponding concepts, which were analyzed in the study, however, the problem of unification of terms inherent in the digital economy needs to be addressed, as well as they should be consolidated in a codified act, which may be embodied in the Law on Digital Economy." In addition to the traditional codified legislation, flexible acts should be developed on its basis that will regulate individual relations arising with the development of the digital economy.

\section{REFERENCES}

[1] N. Levitska, Victoria Digital Technology in Law, Government, Statehood and Law. 2019. No. 9. c. 166. DOI: https://doi.org/10.32849/2663-5313/2019.9.27

[2] P.P. Baranov, Pravovoye regulirovaniye robototekhniki i iskusstvennogo intellekta $\mathrm{V}$ Rossii: nekotoryye podkhody $\mathrm{k}$ resheniyu problemy, SeveroKavkazskiy yuridicheskiy vestnik. 2018. No. 1. s. 39.

[3] M. Gelashvili, Robot na meste sotrudnika banka: fantastika ili real'nost', Bankovskoye obozreniye. 2016. No. 1.

[4] I.A. Filipova, Iskusstvennyy intellekt i trudove otnosheniya: sotsial'nyye perspektivy i tendentsii pravovogo regulirovaniya, Rossiyskaya yustitsiya. 2017. No. 11. s. 66.

[5] T.Ya. Khabriyeva, N.N. Chernogor, Pravo v usloviyakh tsifrovoy real'nosti, Zhurnal rossiyskogo prava. 2018. No. 1. s. 85-102. DOI: https:doi.org/10.12737/art_2018_1_7

[6] T.Ya. Khabriyeva, Pravo pered vyzovami tsifrovoy real'nosti, Zhurnal rossiyskogo prava. - 2018. No. 9. s. 6. DOI: https:doi.org/10.12737/art_2018_9_1

[7] A.I. Ovchinnikov, V.I. Fatkhi, Pravo i tsifrovaya ekonomika: osnovnyye napravleniya vzaimodeystviya, Filosofiya prava. 2018. No. 3(86). s.131.

[8] Digital revolution in Belarus: crypto currency was legalized in Ukraine.URL: https://mind.ua/news/20179963-cifrova-revolyuciya-vbilorusiu-krayini-legalizuvali-kriptovalyuti (26.03.2020).

[9] About Praising Strategies for Developing Informational Suspension in Ukraine: Ordering the Cabinet of Ministers of Ukraine vid 15 grass 2013 p. No. 386-p. URL: http://zakon1.rada.gov.ua//laws/show/ 386-2013-p 
[10] H.B. Sokolova, Deyaki aspekty rozvytku tsyfrovoyi ekonomiky v Ukrayini, Ekonomichnyy visnyk Donbasu. 2018. No. 1(51). C. 93.

[11] Pro skhvalennya Kontseptsiyi rozvytku systemy elektronnykh posluh v Ukrayini : Rozporyadzhennya Kabinetu Ministriv Ukrayiny vid 16 lystopada 2016 r. No. 918-p. URL : https://zakon.rada.gov.ua/laws/show/ 918-2016-\%D1\%80

[12] Pro skhvalennya Kontseptsiyi rozvytku elektronnoho uryaduvannya v Ukrayini : Rozporyadzhennya Kabinetu Ministriv Ukrayiny vid 20 veresnya 2017 p. No. 649-p. URL : https://zakon.rada.gov.ua/laws/show/649-2017-

$\% \mathrm{D} 1 \% 80$

[13] Pro skhvalennya Kontseptsiyi rozvytku elektronnoyi demokratiyi v Ukrayini ta planu zakhodiv shchodo yiyi realizatsiyi : Rozporyadzhennya Kabinetu Ministriv Ukrayiny vid 8 lystopada 2017 p. No. 797-p. URL :https://zakon.rada.gov.ua/laws/show/797-2017$\% \mathrm{D} 1 \% 80$

[14] Zakon Ukrayiny «Pro elektronni dovirchi posluhy» vid 5 zhovtnya 2017 roku No. 2155-VIII // Vidomosti Verkhovnoyi Rady Ukrayiny. 2017. No. 45. Ст.400 URL: https://zakon.rada.gov.ua/laws/show/ 2155-19

[15] Pro skhvalennya Kontseptsiyi rozvytku tsyfrovoyi ekonomiky ta suspil'stva Ukrayiny na 2018-2020 roky ta zatverdzhennya planu zakhodiv shchodo yiyi realizatsiyi : Rozporyadzhennya Kabinetu Ministriv Ukrayiny vid 17 sichnya 2018 p. No. 67-p. URL : https://zakon.rada.gov.ua/laws/show/67-2018-\%D1\%80

[16] Polozhennya pro Ministrestvo tsyfrovoyi transformatsiyi Ukrayiny: Postanova Kabinetu Ministriv Ukrayiny vid 18 veresnya 2019 r.No. 856. URL: https://zakon.rada.gov.ua/laws/show/856-2019$\% \mathrm{D} 0 \% \mathrm{BF}$

[17] Slovo roku 2019. Slovnyk Myslovo. URL: http:// myslovo.com/?page_id=4634 (26.03.2020).

[18] Vinnyk O.M. Rehulyuvannya vidnovyn u sferi tsyfrovoyi ekonomiky: problemy terminolohiyi, Informatsiyne pravo. 2017. No. 11. c. 163-166. 